\title{
(Un)receptiveness in interactions with professionals: experiences of parents of children with retinopathy of prematurity*
}

\author{
(Des)acolhimento nas interações com os profissionais: experiências \\ de pais de crianças com retinopatia da prematuridade \\ (Des)acogida en las interacciones con los profesionales: experiencias \\ de padres de niños con retinopatía de la prematuridad
}

Beatriz Castanheira Facio', Bruna de Souza Lima Marski ${ }^{1}$ leda Harumi Higarashi², Maira Deguer Misko ${ }^{1}$, Aline Oliveira Silveira $^{3}$, Monika Wernet ${ }^{1}$

How to cite this article:

Facio BC, Marski BSL, Higarashi IH, Misko MD, Silveira AO, Wernet M. (Un)receptiveness in interactions with professionals: experiences of parents of children with retinopathy of prematurity. Rev Esc Enferm USP. 2016;50(6):913-921. DOI: http://dx.doi.org/10.1590/S0080-623420160000700006

* Extracted from the dissertation "Caminhando apesar dos limites: o cuidado parental à criança com retinopatia da prematuridade", Programa de Pós-Graduação em Enfermagem, Universidade Federal de São Carlos, 2015.

${ }^{1}$ Universidade Federal de São Carlos, São Carlos, SP, Brazil.

${ }^{2}$ Universidade Estadual de Maringá, Maringá, PR, Brazil.

${ }^{3}$ Universidade de Brasília, Brasília, DF, Brazil.

\begin{abstract}
Objective: To analyze the influence of health professionals' receptiveness on parental care of children with retinopathy of prematurity (ROP). Method: A qualitative study developed under the theoretical framework of Symbolic Interactionism and using a narrative research methodology. Six women and three men, being parents of children with retinopathy of prematurity were individually interviewed in depth. Results: From the scope of information, emotions and their rights, the parents experienced receptiveness from some professionals and unreceptiveness from others. The predominance of unreceptive attitudes in the parental narratives originated the following analysis themes: Informational (un)receptiveness, Emotional (un)receptiveness, and (Un)receptiveness of rights. Conclusion: The study supports human and comprehensive healthcare in the context of retinopathy of prematurity by pointing out the interactive process with health professionals as a potential stressor of parental care. The results signal a nuclear of attitudinal changes and reinforce challenges to the child and family-centered approach.
\end{abstract}

\section{DESCRIPTORS}

Retinopathy of Prematurity; Parents; Professional-Family Relations; Neonatal Nursing; User Embracement. 


\section{INTRODUCTION}

Retinopathy of prematurity (ROP), a complication associated with the premature birth of children, is characterized as abnormal retinal vascularization disorder ${ }^{(1)}$, and blindness stands out among its possible consequences. Its incidence in newborns (NB) with birth weight lower than $1000 \mathrm{~g}$ is around $82.0 \%$, of which $9.3 \%$ evolve into sequelae which threaten vision $^{(2)}$. For the weight range between 1000 and $1500 \mathrm{~g}$, there is a decrease in percentages where $47.0 \%$ of newborns develop ROP and $2.0 \%$ are at risk of losing their sight ${ }^{(3)}$.

These data vary according to locality, and are also influenced by socioeconomic conditions ${ }^{(4)}$. Studies show an incidence of $6.0 \%$ among premature infants born between 24 and 26 weeks of gestation in 2011 in France ${ }^{(5)}$; and between $4.1 \%$ and $38.6 \%$ in Latin America ${ }^{(4)}$. Regarding visual impairment, $\mathrm{ROP}$ is linked to $32.6 \%$ of blindness cases among children under 10 years of age in Vietnam ${ }^{(6)}$.

A study focusing on the impact of prematurity and visual impairment (VI) on parenting has shown that parents suffer in having their idealized dreams for their child interrupted, and have to adapt to a reality permeated by conflicting feelings and fear of the unknown ${ }^{(3)}$. They point out the lack of information about the evolution and prognosis of their child as a promoter of their suffering ${ }^{(3)}$. In the context of VI, the family needs to be recognized as fundamental for the prognosis of the disease and the development of the child, especially through support and information (provided) by the health team ${ }^{(7)}$. However, the relationship with the health professional has been conceived as a critical challenge ${ }^{(8)}$ which generates a paradox, since the chronic illness of the child requires creating bonds and responsibilities between caregivers and health professionals ${ }^{(9)}$.

Despite studies pointing to the importance and the path to quality child care anchored in a process of family integration and preparation, including in the Intensive Care Units ${ }^{(10)}$, there are still relational, attitudinal and institutional weaknesses which impede practice ${ }^{(11)}$. Thus, reflections on the reception of parents, being understood as comprehensive and effective care to the individual ${ }^{(12)}$ in establishing care of children with ROP, have determined the development of this study, and bring forth the guiding questions: How is the receptiveness of parents by health professionals in the experience of baving a VI child caused by ROP? And How do parents perceive health professionals and the care provided in the context of VI as a result of $R O P$ ? The present article represents a section of the results from this research, aiming to analyze the influence of health professionals' receptiveness on parental care of children with ROP.

\section{METHOD}

In selecting interactions of health professionals and parents of children diagnosed with ROP as the object of study, and especially their influence on parental care, narrative research under the theoretical framework of Symbolic Interactionism (SI) has proven to be relevant.

Data collection took place in July 2014 through in-depth interviews, conducted individually at a private location chosen by the interviewee, and with a mean duration of 33 minutes. The following triggering proposition was used: I believe that because of the prematurity and ROP of your child, you have met with several health professionals. Tell me about your relationship with them and how they effectuated care of (child's name).

All the interviews were recorded, transcribed and submitted to narrative analysis under the holistic perspective with an emphasis on the content ${ }^{(13)}$, and adopting the following steps: (1) repeated text readings derived from the narratives to identify the central element/focus of the background; (2) new reiterative and reflexive readings for selecting the terms and excerpts from the narratives that allowed us to extract structuring content for reconstructing the background; (3) interpretive and inductive analysis of the material highlighted in the previous stage aimed at reconstructing a narrative from themes ${ }^{(13)}$.

Throughout data collection and analysis, the researcher is to understand the stories and meanings contained in the data in relation to interactional care processes; meanings therein verbalized and how they were established, as well as their unfolding in terms of social actions, all central to the $\mathrm{SI}^{(14)}$. In this reference, the human being is active in their own experience, someone who interacts, acting in the present through applying past experiences ${ }^{(14)}$.

The subjects of the study were six families (three mothers and three couples composed of one man and one woman) of children diagnosed with ROP. Adopted inclusion criteria were being a biological mother or father of preterm infants born with a diagnosis of ROP and being 18 years or older. Exclusion criteria were any impairment that would prevent comprehensible narratives, or being the parent of twin children and/or those with genetic syndromes/malformations.

The snowball methodology was used as a strategy for locating the subjects, defined as a non-probabilistic sample in which the initial participants of a study indicate another new participant, who successively does the same until the proposed objective is reached, without adding other information relevant to the phenomenon in focus ${ }^{(15)}$, in addition to data collection and analysis occurring concomitantly. The search for new subjects ceased when this situation was achieved.

The process of locating the subjects was initiated within the main investigator's circle of relations, residing in the northern city of Paraná. All study participants were from the municipality of Londrina, a municipality with a population of 506,701 inhabitants in 2010, of which 493,520 are urban residents and 13,181 are rural residents ${ }^{(16)}$. In 2013, the number of births which occurred in this municipality was 8,483 live births, of which 1,248 were born with gestational age less than 37 weeks $^{(17)}$. The municipality has a public neonatal intensive care unit (NICU) reference inserted in a University Hospital (UH), and the children who leave this unit have an outpatient return within the UH itself or in the specialty outpatient clinic, within the Universidade Estadual de Londrina.

The study was approved by the research ethics committee, under CAAE number 29287314.6.0000.55.04 and opinion number 716.611. All participants expressed their agreement upon prior instruction and signing of the Free and Informed 
Consent Form in such a way that all the ethical principles related to research with human beings ${ }^{(18)}$ were duly observed. In order to ensure the confidentiality of the information, the narrative excerpts were identified with the letters ' $M$ ' for the mothers and ' $F$ ' for the fathers, followed by the lower case letter ' $a$ ' to ' $\mathrm{f}$ ' according to the participation sequence of the families. Couples received the same lowercase letters.

\section{RESULTS}

The age of the interviewed mothers ranged from 22 to 33 years, where four were married, one was in a stable union and one was single. All were exclusively stay-at-home mothers; in terms of educational level, two had incomplete higher education, three had completed high school (secondary) education and one had incomplete high school education. Regarding the type of delivery, all were submitted to cesarean sections as justified by: preterm labor with a child in the seated position (2), placenta detachment (2), cervical incompetence (1), specific gestational hypertensive disease and gestational diabetes mellitus (1). Regarding the number of children, one was primiparous, four were multiparous with 2 pregnancies, and one was multiparous with 4 pregnancies. Regarding the fathers, their mean age was between 32 and 40 years old, all were married and employed. With regard to education level, one had incomplete post-secondary education, one had completed high school (secondary education), and one had incomplete elementary/primary education. Reported family income in minimum salaries present during the research period ( $R \$ 724,00$ - BRL) ranged from 1 to 3 minimum wages.

The narrative analyses focusing on interactions with (health) professionals revealed that parents establish their care for a child with ROP under the scope of informational and emotional (un)receptiveness, and (un)receptiveness of rights, as presented in the following thematic units with the same nomenclature.

\section{INFORMATIONAL (UN)RECEPTIVENESS}

Although parents recognize themselves as partners of the child in the process of coping with the health problem condition, for their full exercise in this role they depend on the provision and adequate understanding of information so that they can insert themselves into their parental care praxis. However, incipiences can be perceived in this context, especially in the initial moments of the trajectory where a professional movement toward offering information which portrays the criticality and risk of child death, in addition to those that signal an involution of the condition or the possibilities of sequelae.

They called me in the middle of the night asking me to go there. Because (son's name) had gotten worse and could die. Then what they said was: "look, his infection has worsened, he may not make it. Be Prepared". Only that! Nothing else ... At first this happens a lot, they only call you to talk about bad things (Ff).

I did not receive a lot of explanation, no, it was just that it's serious, serious, very serious, but they (the professionals) did not explain (anything) at the NICU, almost nothing. Then it gets a little bit better $(\mathrm{Mb})$.
Such processes seem to permeate the entire history of the child, with the difference that over time the parents' passivity toward this professional movement is transformed, reflecting the progressive clarity they gain and the strengthened desire to be their child's partners in their therapeutic itinerary and in life. In this sense, they develop a continuous and progressive movement in search of clarification of the situation.

I saw that in the hospital discharge form, everything that he had had was written down, but no one explained it to me properly what he had. (...) He had kidney failure and I only saw it on that paper, I never knew he almost had to undergo dialysis. I only learned about that later, when I tried to understand the reason for his delays. Then the service staff explained it to me because I asked (Mf).

The history of unreceptiveness of information and professional disrespect leads parents to withdraw from it for this purpose. However, they remain vigilant with regard to the care offered to the child in order to identify iatrogenesis or neglect. Suspecting these types of occurrences, they act with tact and prudence requesting clarifications, and in parallel seeking information from other sources, only then to confront the situation.

Then, when he (the doctor) was there, I did not even ask him (doctor) how my son was reacting (...). Now, if the other doctors were there, I used to ask, I questioned about every exam they were conducting, everything that was going on in there. He was able to make me to block him from my life. (...) (Mc).

In addition, the use of technical terms in the limited offerings of information on the child's situation promotes gaps in understanding which make it difficult to determine the direction of their decision-making. A good part of the parents reported using the Internet to seek clarification, while others turned to professionals with whom they had developed a certain bond and trust. It should be noted that the professionals involved in the management of ROP are included in this description. After clarifying their own actions, the parents' worries about VI, and more specifically about the possibility of blindness, caused suffering and curiosity about therapeutic possibilities in relation to ROP and its consequences.

He (doctor) talked to us, but he used a lot of technical terms, so we did not understand it very well. I had to go online and find an easier language, because it was very confusing in those medical terms. I looked it up, I read, I studied, I joined a premature group to share experiences, and only then I had the notion of the problem (ROP) (Mb).

The only mother who had previously experienced prematurity stated that the communication blocks between her and the professionals due to the use of technical terms were mitigated by her previous experience. This aspect facilitated coping of the adversities and maternal care to the child.

So it was easier for me to talk to them, then they would say something and I would say: "This means such, right?" And they would say "oh, you understand!" Then the communication became easier, since I was not so naive in the case of (child's name). There have been several episodes there that if it hadn't been for my experience 
in that period of five months and twenty days inside the hospital, I think I would not have been able to overcome it, right?! (Ma).

Informational support both in the NICU and during follow-up services is not comprehensive and it limits the understanding of the child's situation, thereby compromising more effective parental involvement. The lack of contact with the ophthalmologist in the NICU is highlighted and compared with the follow-up times, when children indicate slight improvements. (Parents) describe that the ophthalmologic follow-up almost (completely) ignores the parents' presence and participation, in addition to focusing on providing information concerning the child's visual conditions. There is no relational opening to welcome questions or establish a joint construction of therapeutic projects, a fact that bothers them and creates a feeling that their child no longer belongs to them.

I know that the ophthalmologist part is that. But because I did not have much contact with the ophthalmologist at NICU, I can't really explain what it is, but the little we know, we deal with it. (...) I started to understand a little bit more about ophthalmological condition of (son's name) here (at the outpatient service), because that was when I started to have a little more contact with the ophthalmology staff(Mf).

However, some parents managed (over time) to establish relationships with the ophthalmologists that allowed them to have some understanding of what the child experiences in terms of ROP.

Usually, when I have an appointment with the ophthalmologist, I always go through the professor as well, helshe takes a look and leaves, we do not have much contact; but with the students, at least the staff who care for (son's name), they answer the things I ask (...) (Ma).

I remember when I was in the ICU they told me, they explained to me that when a baby is very premature their (eye vessels') development/reach is not complete, I can't explain terms, but the doctor explained that there was a vessel that was supposed to reach the end and that it was interrupted in the middle. So, even after being born, these little vessels were still trying to develop, but his, because of the retinopathy, because he was premature, his were not developing $(\mathrm{Mb})$.

\section{EMOTIONAL (UN)RECEPTIVENESS}

Emotional (un)receptiveness is associated to informational (un)receptiveness. By establishing narratives about this modality of (un)receptiveness, the parents emphasized the ability of the professional to become aware of the family's situation, being able to demonstrate this aspect. Thus, the parents related the presence of such an attribute as an inducer for implementing a more supportive attitude or posture.

There were many doctors, Doctor (name) when I got there the second time with (son's name), he was purple on my lap, dying, when he saw that situation, he hugged me, he cried with me and he said: "Calm down, I'll do anything I can do for your son, but I just want you to understand that down here there is nothing we can do for him, he's going to have to go up (up into the NICU) and that's what I can do for him now, for him to get better!" (Mc).
They (the nurses) always belped us, they were always aware, they knew what was happening and what we were going through $(\mathrm{Fe})$.

In this context, parents value professional behavior aimed at sharing events with the child and teaching the child's specific care. They interpret such acts as a demonstration of respect and consideration towards them. However, they indicated that few professionals had such characteristics.

The girls (nursing techniques and residents) taught me a lot! How to bathe (him), how to hold (him), how to care (for him), what to do, how to change (his diapers and clothes), everything. (...) It was very good, very easy (Mc).

They (the professionals) taught us how to pick them up, how to clean them, that we could not open the incubator, they taught the "kangaroo" (skin-to-skin), which was a great thing! How to bathe them too. Wow! It was super perfect ... all the things they taught us, it was perfect! It shows that they consider us, it's a shame that there are so few of them... (Md).

In this same direction as pointed out above, they could identify some professional efforts which resolved their and their child's needs.

He explained that the $\mathrm{ml}$ of the thing to put in their eyes cost three thousand reais (Brazilian currency - BRL), but he said he was going give him his! Because he had some in his office, and it had to be done quickly and he knew we would not be able to raise the money like this, from day to night, so he gave it. Wow! My beart calmed! (Mb).

There are relationships with professionals that perpetuate in the life trajectory of the family and child as structured in the demonstration of interest and concern on the part of the professional in relation to the well-being and development of the child, as well as those of the family. Such relationships are viewed by families as a learning for life, and as a sort of confirmation of the thesis that there are people in the world available and committed to helping. The configuration of this bond and an atmosphere of belonging contribute to the significance of the team as "family".

(...) every now and then they (doctors and nurses) ask: "how is (son's name)? How is our prince?" It's like I said, they end up becoming our family. (Ma).

(...) there have been many doctors who have taken care of him as if he was their little boy, it was very good, such learning. (...) Because there are lots of residents, because there are lots of interns, they help us a lot. They are always willing to help, to teach what little they know or as much as they know, to share an experience, it is great! I say they are my second family now, because if there's anything I need that's where I rush to (...). (Mc).

However, generally interactions with professionals are predominantly marked by attitudes of indifference towards parents and children, and by a posture of disregard in relation to the developmental possibilities of this. This aspect has a direct impact on the perception of quality, satisfaction and parental trust related to professional care. Due to this, although parents value the competence and clinical skill of the professional, they also highlight the importance of the degree of relational availability and affection demonstrated in daily therapeutic routine. 
I did not really like the professionals who attended me until now, not really. I think they treated the child with a lot of indifference ... today I went to the neurologist and she didn't even touch him... (...) she did not notice how smart/aware he is, did not see that he is walking and holding things, she did not see anything! It makes us want more, right?! (...) For me it is not precise, because she did not evaluate him ... Dissatisfaction is the word that defines it $(\mathrm{Mb})$.

Specifically in the context of school hospitals, parents witness dialogues between medical students (internal and resident) and their teaching supervisors, to whom they convey insecurities and uncertainties in the diagnostic process. The times they witnessed/noticed supervision by the teacher focused on a considerate attitude towards the parents were rare, and thus the occurrence of this type of intervention was emphasized.

Then, once her teacher asked her if I knew what was happening. From that moment on she began to change, she began to explain, at every consultation she began to give me the results, because before that I had no idea (...) (Mc).

Only after did I understand what the disease was and that this follow-up was going to be good because it was going to avoid this retinal detachment, it was more that first month that was complicated. (...) Then she started explaining what retinopathy was. It calmed me down, but I was still worried that if he reached degree four, he would necessarily have to do the laser surgery (Me).

Therefore, in the context of "school services", the parents showed an expectation of being attended by professionals with whom they had already established previous bonds, mainly consolidated by sincerity and honesty in the dialogues.

They are the two doctors I like from the bottom of my heart, every time I go to the hospital, I pray they're there, because they were always honest in what they had to say, I always agreed with the fact that nothing should be bidden (Fc).

\section{(UN)RECEPTIVENESS OF RIGHTS}

Inadequacies of attitude and insufficiencies in professional commitment expressed in care acts constitute limits on the reception of needs, either in information or on emotions, leading to the understanding of having their experience devalued or reduced, as if they were not subjects with rights. Among the issues that most impact in this direction is the straightforward and sometimes rude manner to interact with the parents, denoting insensitivity, dissent, especially in the hospitalization period in the NICU and by the teaching doctors of the university hospital. This attitude has negative consequences in relation to hope and struggle, it generates anger, especially in men, with a strong desire for confrontation (usually contained), as exemplified by fathers remembering their interaction with the doctor in the first visit to see their child in the NICU:

"Oh, Mother, if he does not leave here today, he will never leave again." I stopped, took a deep breath, I had just gotten up, then I started to feel sick, the nurses came and helped me. Then, (husband's name) who is very short-tempered wanted to get in there, start a fight... I felt really bad, I lost my nerve, I lost hope (...) (Mc).
Sometimes the doctor is dry, it's the way the guy is, a teacher, right? ... He even looked her (the wife) in the eyes and said, "Oh, we did what we could, now if there's no reaction in the next twenty-four hours, I'm sorry." He assumed the kid as dead, when he said that I jumped, I said: "No, wait, that's not how you are going to talk!" I just did not get into an argument with him because she (wife) did not let me, because I was going to argue for the way we was speaking, you know?! (...) ( Fc).

Also, in this context of (un)receptiveness of rights, there is the existence of an extra stressor in the paternal experience. The men signaled the presence of gender issues by not being considered as a reference for professionals in matters relating to the child in the NICU. At this site, they noticed an exclusive searching movement for the mothers, even when the fathers were present. Thus, information about their children came to them only through their wives. The exceptions were rare. Of the three fathers heard in this study, one stressed this limit, and he questioned his rights and his social role, clearly exposing his irritation and annoyance at such an attitude.

With the father it is different, when he (the child) was hospitalized there (NICU), usually the mother had to be around, they never spoke with the father. This was always said (by professionals): "Ob no, where's the mother? Is she here?"(...). All the times we had a conversation, she (mother's name) was by my side (...) I was very uncomfortable, I thought: "Am I only bere to bring bim here and take bim back? Don't I have any right to know what's going on? Am I nobody?” (Fc).

This means somehow participation in the child's life was 'denied' to the fathers, a condition desired and sought by them. That is, the exercise of fatherhood was denied.

I like to know what's going on with my kids, you know?! If I have to take a vacation, if I didn't have to work, I wouldn't work so I could stay near them (...). I even thought it was strange, you know?! I got there sometimes and it was just me, I stayed there all day (...) it's my way, I wanted to be close $(\mathrm{Fc})$.

Another issue related to the sphere of rights is in relation to the child as a person, and the guarantee of parental participation in the decision of the therapeutic plan. In this issue, ophthalmologic care is the scenario of rights denial, especially related to questions that permeate the eye examination; this is a frequent procedure in these children and is perceived by the parents as an invasive and painful procedure, determinant of prognosis and therapeutic behaviors. There are eyewitness testimonies of the child's painful manifestations and the insensitive and 'cold' attitude of ophthalmologists in relation to such behavior. They notice a professional focused on the diagnostic procedure, removing the child from the context. They also point out that these professionals seem to expect a similar behavior from the parents, based on the justification that it is for the good of the child.

The funduscopy is horrible! They put that thing in the child's eye and they cry, they turn red. There's no way to think that it does not hurt, so the doctor needs to be good, only a few are. To make matters worse, they don't even tell the results, I only met one (doctor) who talked about it (Ff). 
I don't know if they are considered doctors, right?! But she was angry with me in there, she said: "What is the point of crying?" And I said, "I cry, yes! Why don't you put that thing in your eye?" Imagine his distress, this thing poking inside the baby's eye! She said, "Mother, but it's for his own good, if you're nervous, go outside, I'll stay in here." (Mc).

The "lack of humanity" in the opinion of the parents would be due to the lack of love for people and the profession. The exercise of the medical profession is only based on financial return.

A lousy one (doctor), who is only there for the money and not for what it serves. I see that he is only there to earn his salary at the end of the month (...) because when you love what you do, you love the people behind it (...). And for me, he's not a professional (Mc).

From the preceding, it is noticed that the parents experience instability in receptiveness, and whenever possible they try to avoid situations that they imagine or know promote disrespect. This action helps them to carry out their partnership with their child more smoothly and with less emotional wear, thus optimizing their efforts towards the child's development.

\section{DISCUSSION}

The intersubjective interactions between those involved in and with healthcare practice manifest themselves in care, a fundamental device for the comprehensiveness of healthcare ${ }^{(19)}$. Healthcare is a singular act focused on the well-being of the subjects involved in it, and requires fruitful interactions that require consideration in the sense of being of such subjects ${ }^{(20)}$, which requires investments in sensitivity by the professional ${ }^{(21)}$.

In the context of ROP, working together with parents is essential for prevention and treatment steps, with it being necessary to clarify and understand that the diagnosis often emerges as a new stressor in the scenario permeated by the (un)stableness of the child ${ }^{(4)}$. However, the parents in this study portrayed that the majority of interactions with health professionals had diagnostic and therapeutic processes related to prematurity and its complications as their motto, with ROP and interactions with ophthalmologists among them. They describe these interactions as normative, almost molded from a pre-planned script in terms of procedures and plot which, specifically with regard to ROP, deal with continuous diagnostic evaluations, including the funduscopy and are permeated by uncertainty and little effort in using language and communication that can involve parents in the process.

The funduscopy is a procedure that imposes agony and suffering on the parents as it is associated to a painful and invasive procedure. Literature provides different strategies for pain relief in neonatology, including $25.0 \%$ sucrose and breast milk, both indicated and with a positive effect on pain reduction caused by the eye fundus examination ${ }^{(22)}$.

Another aspect appreciated in this and in another study ${ }^{(23)}$ was the importance of transforming linguistic barriers, mainly related to technical jargon as they constitute limits to dialogue and to intersubjectivity ${ }^{(20)}$. For the parents of this study, the ROP diagnosis involved a lack of knowledge about the pathology and a lack of more detailed information about it, along with developments related to constructing child care; a fact also identified in a study aimed at knowing the difficulties and facilities faced by mothers caring for children with visual impairment ${ }^{(7)}$. Knowledge acquisition about VI therefore represents an important contribution to the effectiveness of family care to the child ${ }^{(7)}$.

Thus, the dual and incipient relationship in the informational framework established between parents and health professionals in caring for children with $\mathrm{ROP}$ has a negative impact on parenting. This situation is stressful, since after facing the fear of death, parents still need to adapt to the new diagnosis conditions, which do not have immediate discovery at birth as a particularity ${ }^{(3)}$.

The care space cannot be restricted to technical acts; it must be broadened in order to allow subjects to develop connection, concern and consideration for each other. It requires active and empathic listening from the health professional that, if present, attributes quality to the care ${ }^{(22)}$. In this sense, professional health training needs to be actively involved in such a challenge ${ }^{(21)}$. "The act of caring cannot only be a small subordinate task of health practices" ${ }^{\prime 20)}$. It is an attitude pervaded by willing, and this is an attribute and an act of being, to be considered in the process of mutual project construction $^{(20)}$. The parents heard in this study reported feeling little cared for by the professionals, especially due to an absence of dialogue and bond that allowed for mutuality in constructing care plans. In general, the professionals presented themselves with "ready-made projects" to be imposed on "target subjects", and almost exclusively focused on diagnosing and controlling the disease (ROP among them) as a way of promoting health.

There is an urgent need to break static and objective relations(ships), and in this sense, three movements are highlighted "from subject to intersubjectivity; from technical control to practical success; from treating to caring" ${ }^{\prime 20)}$. In this sense we emphasize the need to value dialogue and emphasize language as a means of mutual "engenderment of subjects, since it is in it that the presence of the other is manifested, as well as ours, so that the otherness of both is revealed"(20).

In this study, communication between the health team and the parents was confined as a limit to parental care development for not being effective in promoting understanding of the child's situation. This fact appeared to stem from a restricted supply of information and clarification, in addition to using technical terms, little or no contact with the professional, and even parental withdrawal from this discourteous behavior.

The limits expressed above define toxic communication characterized by an impersonal and purely technical approach that, in turn, makes humanized and therapeutic care provision impossible. In addition, they characterize themselves as promoters of suffering by hurting the family's right to obtain information concerning the diagnosis and to be attended to in their needs. 'Giving orders and moral lessons, contradictory messages and ignoring the patient's problem' are also reported as harmful communication during the 
family experience of child hospitalization, mainly because they exacerbate the vulnerability of this unit ${ }^{(24)}$.

The family's role as a resource for coping with situations of chronic illness in childhood is (already) known ${ }^{(25)}$, as well as their contribution to care that promotes the child's development ${ }^{(26)}$. Hence, the relevance in supporting conflict resolution and/or resolving family anxieties in these scenarios. The health professional has this role, especially when it is in line with the recommendations of a child-centered approach, a sine qua non condition for reaching the humanization and comprehensiveness of care necessary for the health practices of a child living with illness chronicity ${ }^{(27)}$.

Questions arise as to the new forms of exercising fatherhood, in which men claim to be inserted in issues that refer to the child ${ }^{(28)}$, a fact that was present in this study. Child care as a family role requires consideration and recognition of fatherhood, which is felt and experienced in a particular way ${ }^{(29)}$.

During the child's hospitalization at the NICU, parents expressed a desire to perform their paternal role, but this was hampered by the lack of information about the child since the professionals had the mother as a reference. This finding is in line with literature ${ }^{(29)}$ reports; that gestation and parenthood are still attributes conceived as being (only) related to the woman, distancing the father from the child and his care. Thus, feeling welcomed/received and understanding what happens to the child is also essential to them.

\section{CONCLUSION}

Interactions with professionals were pointed out as limiting parental care for the child with ROP, mainly due to communicational incipience, and marked by informational, emotional and rights withdrawal. In this context, we emphasize a paternal experience marked by more restrictions, caused by the tendency to consider the woman as the sole reference for the child's affairs. In this way, intersubjectivity is considered as a pressing challenge in professional practices and family-centered healthcare.

This study broadened the qualitative evidence within the scope of ROP, with contributions to human and comprehensive healthcare by bringing forth elucidations on how to qualify the interpersonal relationship between parents and professionals. It has the limitation of only being from the parental perspective, and we suggest an extension to the professional perspective. Another unintended limitation concerns the characterization of such parents: they were all residents of the same municipality, with extremely preterm infants from the same university hospital NICU. Thus, we suggest further studies with parents and professionals in other care contexts.

However, the approach employed in this study transcends that of others that are restricted to a therapeutic and diagnostic focus, and those rare ones that qualitatively explore events inherent to the experience of having/caring for a child with ROP. Thus, this study is innovative in the sense of addressing this issue, while also contemplating the perception of parents (men and women), a fact that breaks the tendency of only interviewing mothers.

The emphasis on interaction has reinforced the value and role of dialogue, language, and intersubjective interactions as care constituents; thus, it merits investment, and still represents a challenge in the path towards healthcare qualification, including vocational training.

\section{RESUMO}

Objetivo: Analisar a influência do acolhimento do profissional de saúde no cuidado parental junto ao filho com retinopatia da prematuridade. Método: Estudo qualitativo desenvolvido sob o referencial teórico do Interacionismo Simbólico e metodológico da pesquisa de narrativas. Foram entrevistados em profundidade e individualmente seis mulheres e três homens, pais de crianças com retinopatia da prematuridade. Resultados: Os pais vivenciam, nos âmbitos informacional, emocional e de direitos, acolhimento com alguns profissionais e destrato com outros. A predominância da postura de desacolhimento nas narrativas parentais deu origem aos temas de análise: (Des)acolhimento informacional, (Des)acolhimento emocional, e (Des)acolhimento de direitos. Conclusão: O estudo oferece subsídios ao cuidado humano e integral em saúde no contexto da retinopatia da prematuridade ao apontar o processo interativo com os profissionais de saúde enquanto potencial estressor do cuidado parental. Os resultados sinalizam núcleos de mudanças atitudinais e reforçam desafios à abordagem centrada na criança e família.

\section{DESCRITORES}

Retinopatia da Prematuridade; Pais; Relações Profissional-Família; Enfermagem Neonatal; Acolhimento.

\section{RESUMEN}

Objetivo: Analizar la influencia de la acogida del profesional sanitario en el cuidado parental ante el hijo con retinopatía de la prematuridad. Método: Estudio cualitativo desarrollado bajo el marco de referencia teórico del Interaccionismo Simbólico y metodológico de la investigación de narraciones. Fueron entrevistados en profundidad e individualmente a seis mujeres y tres hombres, padres de niños con retinopatía de la prematuridad. Resultados: Los padres vivencian, en los ámbitos informativo, emotivo y de derechos, la acogida de algunos profesionales y el destrato de otros. La predominancia de la postura de (des)acogida en las narraciones parentales dio origen a los temas de análisis: (Des)acogida informativa, (Des)acogida emotiva y (Des)acogida de derechos. Conclusión: El estudio brinda subsidios al cuidado humano y completo en salud en el marco de la retinopatía de la prematuridad al indicar el proceso interactivo con los profesionales sanitarios como potencial de estrés del cuidado parental. Los resultados señalan núcleos de cambios de actitud y refuerzan desafíos al abordaje centrado en el niño y la familia.

\section{DESCRIPTORES}

Retinopatía de la Prematuridad; Padres; Relaciones Profesional-Familia; Enfermería Neonatal; Acogimiento. 


\section{REFERENCES}

1. Schumann RF, Barbosa ADM, Valete CO. Incidência e gravidade da retinopatia da prematuridade e sua associação com morbidade e tratamentos instituídos no Hospital Universitário Antonio Pedro, entre 2003 a 2005. Arq Bras Oftalm [Internet]. 2010 [citado 2016 mar. 15];73(1):47-51. Disponível em: www.scielo.br/pdf/abo/v73n1/v73n1a08.pdf

2. Isenberg SJ. Distúrbios oculares. In: Macdonald MG, Mullett MD, Seshia MMK. Neonatologia: Fisiopatologia e tratamento do recémnascido. Rio de Janeiro: Guanabara Koogan; 2010. p. 1350-64.

3. Kreutz CM, Bosa CA. "Um sonho cortado pela metade...": estudo de caso sobre o impacto da prematuridade e da deficiência visual do bebê na parentalidade. Estud Psicol [Internet]. 2014 [citado 2015 out. 15];18(2):305-13. Disponível em: www.scielo.br/pdf/epsic/v18n2/ v18n2a16.pdf

4. Darlow BA, Gilbert CE, Quiroga AM. Setting up and improving retinopathy of prematurity programs: interaction of neonatology, nursing, and ophthalmology. Clin Perinatol. 2013;40(2):215-7.

5. Ancel PY, Goffinet F, EPIPAGE-2 Writing Group. Survival and morbidity of preterm children born at 22 through 34 weeks' gestation in France in 2011: results of the EPIPAGE-2 Cohort Study. JAMA Pediatr. 2015;169(3):230-8.

6. Limburg H, Gilbert C, Dung NC, Hoang TH. Prevalence and causes of blindness in children in Vietnam. Ophthalmology. 2012;119(2):55-61.

7. Pintanel AC, Gomes GC, Xavier DM. Mães de crianças com deficiência visual: dificuldades e facilidades enfrentadas no cuidado. Rev Gaúcha Enferm [Internet]. 2013 [citado 2016 mar 15];34(2):86-92. Disponível em: http://seer.ufrgs.br/RevistaGauchadeEnfermagem/article/ view/30729

8. Gil AC. Como elaborar projetos de pesquisa. 5ª ed. São Paulo: Atlas; 2010.

9. Castellanos MEP. The narrative in qualitative research in health. Ciênc Saúde coletiva [Internet]. 2014 [cited 2016 Mar 15];19(4):1065-76. Available from: http://www.scielosp.org/pdf/csc/v19n4/en_1413-8123-csc-19-04-01065.pdf

10. Cockcroft S. How can family centred care be improved to meet the needs of parents with a premature baby in neonatal intensive care? J Neonatal Nurs. 2012;18(3):105-10.

11. Coyne I. Families and health-care professionals' perspectives and expectations of family-centred care: hidden expectations and unclear roles. Health Expect. 2015;18(5):796-808.

12. Brasil. Ministério da Saúde. Secretaria de Atenção à Saúde, Núcleo Técnico da Política Nacional de Humanização. HumanizaSUS: documento base para gestores e trabalhadores do SUS [Internet]. Brasília; 2006 [citado 2015 out. 15]. Disponível em: bvsms.saude.gov. $\mathrm{br} / \mathrm{bvs} / . . . /$ humanizasus_gestores_trabalhadores_sus_4ed.pdf

13. Lieblich A, Tuval-mashiach R, Zilber T. Narrative research: reading, analysis and interpretation. Thousand Oaks: Sage; 1998.

14. Charon JM. Symbolic interactionism: an introduction, an interpretation, an integration. 10 th ed. Boston: Prentice Hall; 2010.

15. Brasil. Ministério da Saúde; Conselho Nacional de Saúde. Resolução n. 466, de 12 de dezembro de 2012. Dispõe sobre diretrizes e normas regulamentadoras de pesquisas envolvendo seres humanos [Internet]. Brasília; 2012 [citado 2015 out. 15]. Disponível em: http://conselho. saude.gov.br/resolucoes/2012/Reso466.pdf

16. Baldin N, Munhoz EMD. Educação ambiental comunitária: uma experiência com a técnica de pesquisa snowball (bola de neve). Rev Eletr Mestr Educ Ambient [Internet]. 2011 [citado 2016 mar. 15];27:46-60. Disponível em: https://www.seer.furg.br/remea/article/view/3193

17. Brasil. Ministério da Saúde. DATASUS. Sistema de Informações sobre Nascidos Vivos (SINASC). Nascidos vivos $1994-2012$ [Internet]. Brasília; 2016 [citado 2016 mar. 15]. Disponível em: http://www2.datasus.gov.br/DATASUS/index.php?area=060702

18. Brasil. Ministério da Saúde. DATASUS. Informações em Saúde [Internet]. Brasília; 2013 [citado 2016 mar. 15]. Disponível em: http://www2. datasus.gov.br/DATASUS/index.php?area=04

19. Ayres JRCM. Cuidado: trabalho e interação nas práticas de saúde. Rio de Janeiro: ABRASCO; 2009.

20. Formozo GA, Oliveira DC, Costa TL, Gomes AMT. As relações interpessoais no cuidado em saúde: uma aproximação ao problema. Rev Enferm UERJ [Internet]. 2012 [citado 2016 mar. 15];20(1):124-7. Disponível: www.facenf.uerj.br/v20n1/v20n1a21.pdf

21. Adamson E, Dewar B. Compassionate Care: Student nurses' learning through reflection and the use of story. Nurse Educ Pract. 2014;15(3):155-61.

22. Ribeiro LM, Castral TC, Montanholi LL, Daré MF, Silva ACA, Antonini SRR, et al. Human milk for neonatal pain relief during ophthalmoscopy. Rev Esc Enferm USP [Internet]. 2013[cited 2016 Mar 15];47(5):1039-45. Available from: http://www.scielo.br/pdf/reeusp/v47n5/00806234-reeusp-47-05-1039.pdf

23. Milbrath VM, Siqueira HCH, Motta MGC, Amestoy SC. Comunicação entre a equipe de saúde e família da criança com asfixia perinatal grave. Texto Contexto Enferm [Internet]. 2011 [cited 2016 Mar 15];20(4):726-34. Available from: www.scielo.br/pdf/tce/v20n4/11.pdf

24. Santos LF, Oliveira LMAC, Munari DB, Barbosa MA, Peixoto MKAV, Nogueira ALG. Quando a comunicação é nociva no encontro entre profissional e família da criança hospitalizada. Enferm Global [Internet]. 2015 [citado 2016 mar. 15];14(37):204-15. Disponível em: http:// scielo.isciii.es/pdf/eg/v14n37/pt_docencia4.pdf

25. Nishimoto CLJ, Duarte ED. A organização familiar para o cuidado à criança em condição crônica, egressa da unidade de terapia intensiva neonatal. Texto Contexto Enferm [Internet]. 2014 [citado 2016 mar. 15];23(2):318-27. Disponível em: http://www.scielo.br/pdf/tce/v23n2/ pt_0104-0707-tce-23-02-00318.pdf

26. Castilho CN, Gontijo DT, Alves HC, Souza ACA. "A gente tenta mostrar e o povo não vê": análise da participação de pessoas com cegueira congênita nos diferentes ciclos da vida. Cad Ter Ocup UFSCar [Internet]. 2011 [citado 2016 mar. 15];19(2):189-211. Disponível em: http:// www.cadernosdeterapiaocupacional.ufscar.br/index.php/cadernos/article/viewFile/461/326

27. Baltor MRR, Matos APK, Wernet M, Ferreira NMLA, Dupas G. The perceptions of families with children having chronic diseases and their relationships with healthcare professionals. Rev Esc Enferm USP [Internet]. 2013 [cited 2016 Mar 15];7(4):808-14. Available from: http:// www.scielo.br/pdf/reeusp/v47n4/en_0080-6234-reeusp-47-4-0808.pdf 
28. Poh HL, Koh SS, Seow HC, He HG. First-time fathers' experiences and needs during pregnancy and childbirth: a descriptive qualitative study. Midwifery. 2014;30(6):779-87.

29. Cúnico SD, Arpini MD. A família em mudanças: desafios para a paternidade contemporânea. Pensando Fam [Internet]. 2013 [citado 2016 mar. 15];17(1):28-40. Disponível em: http://pepsic.bvsalud.org/pdf/penf/v17n1/v17n1a04.pdf

Financial support: Coordenação de Aperfeiçoamento de Pessoal de Nível Superior (CAPES). 